\title{
Overwinter mortality and spring growth in selected and non-selected juvenile Mercenaria mercenaria
}

\author{
Chester B. Zarnoch ${ }^{1, *}$, Matthew Sclafani ${ }^{2}$ \\ ${ }^{1}$ Department of Natural Science, Baruch College, City University of New York, New York, New York 10010, USA \\ ${ }^{2}$ Cornell University Cooperative Extension, Riverhead, New York 11901, USA
}

\begin{abstract}
Juvenile cultured northern quahogs or hard clams Mercenaria mercenaria can experience significant mortalities during their first winter, and cultured M. mercenaria var. notata clams, selected for fast growth, may be more susceptible. In the present study, selected and non-selected juvenile clams were overwintered off the north shore of Long Island, NY from November 2007 to June 2008 in order to understand the physiological, genetic, and environmental mechanisms contributing to overwinter mortality. Selected clams had a cumulative mortality of approximately $47 \%$ while the non-selected clams experienced $25 \%$ mortality. A decrease in carbohydrate reserves coincided with the mortality in both clam strains, but time-specific loss of carbohydrates was greater in the selected clams. Metabolic activity, as estimated by the activity of the electron transport system (ETS), was high during the winter-to-spring transition and was later reduced, presumably when clams became acclimated to the warmer temperature in May. Growth occurred after the observed reduction in ETS activity and was greater in the selected clams. This reduction in metabolic activity may allow for the balance of available energy to switch from maintenance to growth. These results support previous work suggesting a genetic component to overwinter mortality and demonstrate the significant effects of seasonal transitions on hard clam growth and energetics.
\end{abstract}

KEY WORDS: Hard clam · Mercenaria mercenaria var. notata $\cdot$ Overwinter mortality $\cdot$ Aquaculture Biochemical composition · Metabolism · Growth · Energy

\section{INTRODUCTION}

The hard clam, Mercenaria mercenaria, has historically been an important marine resource in the USA (Belding 1912) and has now become an important aquacultured product. The success of hard clam aquaculture and stock enhancement programs is impeded from the mid-Atlantic region north through to Atlantic Canada due to excessive mortality over the winter (Bricelj et al. 2007, Zarnoch \& Schreibman 2008). Although predation can have a significant impact on juvenile hard clam populations (Ford 2001, Kraeuter 2001), overwinter mortality has also been observed in populations protected from predators. This suggests physiological and/or environmental mechanisms contribute to the mortality. This mortality was shown to be variable from year to year and from site to site (Zarnoch \& Schreibman 2008). Furthermore, recent evidence suggests that juvenile hard clams selected for fast growth may be more susceptible to overwinter mortality. Thus selection for fast growth may be associated with physiological trade-offs with other fitnessrelated traits (Angilletta et al. 2003, Bayne 2004).

Zarnoch \& Schreibman (2008) have shown that significant mortality (up to $1 \% \mathrm{~d}^{-1}$ ) occurs in the spring following a severe winter, at a time when water temperatures are rising but food levels are low. During this period, a rapid decline in carbohydrate content is observed. The clams, which are inactive at $<5^{\circ} \mathrm{C}$ (Loosanoff 1939), are stimulated by an increase in water temperature. The increase in metabolic activity should be supported by the ambient food supply, but if food levels are low or nutritional quality of the food is poor, the clams must rely on stored carbohydrates to maintain the increased metabolic activity. Mortality occurred when carbohydrate levels fell below $10 \%$ of the 
tissue dry weight (DW) and has been termed 'winterspring mortality' (Zarnoch \& Schreibman 2008).

A loss of carbohydrates has also been associated with overwinter mortality in studies conducted in Atlantic Canada. In laboratory experiments, juvenile clams (6 to $8 \mathrm{~mm}$ shell length [SL]; obtained from an aquaculture facility in Massachusetts, USA) were held at $1^{\circ} \mathrm{C}$ for $\sim 12 \mathrm{wk}$. There was a linear decrease in carbohydrate content together with significant mortality $(\sim 70 \%)$. In addition, clams held at $7^{\circ} \mathrm{C}$ also experienced significant mortality $(\sim 50 \%)$, suggesting that this temperature also caused physiological stress. Clams held at $12^{\circ} \mathrm{C}$ experienced no significant mortality (Bricelj et al. 2007). Although the relationship between mortality and carbohydrates is similar to the findings of Zarnoch \& Schreibman (2008), the timing of the mortality was not associated with spring warming since the clams were held in the laboratory at different constant temperatures for several months. This suggests that an alternative environmental or physiological mechanism might be responsible for the mortality. Another intriguing finding of Bricelj et al. (2007) is that in separate trials, clams selected for fast growth and held at $1{ }^{\circ} \mathrm{C}$ experienced $70 \%$ mortality versus $30 \%$ mortality for non-selected clams held under identical conditions. This was the first work to suggest a genetic component to the overwinter mortality of juvenile hard clams.

Laboratory studies by Pernet et al. (2006) demonstrated that oxygen consumption was $\sim 33 \%$ lower in non-selected versus selected hard clams, suggesting that there may be an energetic advantage to coldadapted clams reducing their energetic needs during overwintering. If metabolic rates were higher in selected clams in the field during spring warming when food levels were low (as in the model proposed by Zarnoch \& Schreibman 2008), greater mortality would be expected in these clams due to their higher, unmet metabolic demands. This hypothesis requires testing, but measures of oxygen consumption have limitations when used in field studies. The individuals can become stressed due to handling, simulating food and sediments is problematic, and results may not be indicative of ambient field conditions (Cammen et al. 1990). An alternative methodology to estimate oxygen utilization in a way more suitable for in situ studies is the measurement of the activity of the electron transport system (ETS). This assay estimates total aerobic potential of an organism by measuring the activity of the rate-limiting step in $\mathrm{O}_{2}$ utilization for ATP production. It has been used to measure potential $\mathrm{O}_{2}$ utilization in bivalves and correlates well with direct measures of oxygen utilization (Madon et al. 1998, Fanslow et al. 2001, García-Esquivel et al. 2001).

The overwinter mortality of selected and nonselected clams was compared in a combined field and laboratory study (Gionet et al. 2009) in eastern Canada. Mortality was negligible in both the field and laboratory from August through April, but increased markedly in May. Mortality up to $50 \%$ was observed in selected clams, while the non-selected clams had mortality of $\sim 10 \%$. The authors found a lower concentration of glucose and lipids in the selected clams and suggested that the higher glucose concentration in the non-selected clams may help reduce the freezing point of the clams' fluids, thus improving survival.

In the present study, selected and non-selected juvenile clams were overwintered under in situ conditions off the north shore of Long Island, NY in order to: (1) determine if selected clams experience greater overwinter/ winter-spring mortality than non-selected clams, (2) determine if greater metabolic activity during spring warming results in higher mortality in selected clams, and (3) use a comparative approach to better understand the physiological, genetic, and environmental mechanisms responsible for overwinter mortality in selected and non-selected clams.

\section{MATERIALS AND METHODS}

Stock populations. Experimental Mercenaria mercenaria populations of both strains (selected and not selected for fast growth) were produced in spring 2007 by the Cornell Cooperative Extension Shellfish Hatchery, Centerport, NY, using standard hatchery procedures (Castagna 2001). However, this hatchery does not cull small or slow-growing clams during the larval and nursery phases. Non-selected clams were produced from wild broodstock collected from the Greater Huntington-Northport Harbor Complex (Huntington, NY). The selected clams were produced from broodstock obtained from the Frank M. Flowers \& Sons Shellfish Hatchery (Oyster Bay, NY). These selected broodstock are $M$. mercenaria var. notata, which is a naturally occurring variant with brown zigzag bands on the shell (Chanley 1961). They grow faster than wild stock. Since notata clams occur in very low frequencies in natural populations (Chanley 1961, Humphrey \& Walker 1982), aquaculturists breed this trait into clams to distinguish cultured clams from wild clams. Summer grow-out of the juvenile clams was performed in Huntington Harbor (Huntington, NY) using a floating upwelling system. Through the entire production and grow-out process, both strains were treated identically. In November 2007, clams of a common SL ( 11 mm) were chosen for the study.

Experimental design and sampling. The overwintering study was conducted from November 2007 to June 2008 at Centerport Harbor on the north shore of Long Island, NY. The clams were deployed in wooden boxes 
$(30 \times 30 \times 15 \mathrm{~cm})$ with a closed bottom and an open top covered with $6.4 \mathrm{~mm}$ aperture plastic mesh after stocking to exclude predators and retain the clams. Each was filled with sediment from the study site that was sieved to $<12 \mathrm{~mm}$. Thirty clams of either the selected $(10.74 \pm 0.23 \mathrm{~mm} \mathrm{SL})$ or non-selected $(10.68 \pm 0.99 \mathrm{~mm}$ SL) clams were stocked in each box. A total of 100 boxes were numbered and deployed subtidally $(\sim 1 \mathrm{~m}$ depth at mean low water) at the site. The boxes were placed directly on the bottom and spaced $\sim 0.5 \mathrm{~m}$ apart. Half of the boxes $(n=50)$ contained selected clams and the other half contained non-selected clams. At monthly intervals from December through March, 5 boxes containing the selected clams and 5 boxes containing the non-selected clams were sampled. From April through June the remaining boxes were sampled biweekly and either 5 or 10 boxes (June) were sampled for each clam strain.

At each sampling, all sediment from a box was sieved over a $2 \mathrm{~mm}$ mesh at the site. Live and dead clams (identified as 'gaping' or a 'clapper') were enumerated and percent cumulative mortality (\%MO) was calculated directly for each box as: $\% \mathrm{MO}=$ (dead clams/total clams) $\times 100$. The boxes were treated as replicate plots and the mean \%MO for each sampling date was determined from these replicates. Water temperature at the site was measured twice per day by an in situ temperature logger (Onset) and is shown as the mean temperature $( \pm \mathrm{SE})$ for the periods between consecutive sampling dates. On each sampling date, water samples were collected and analyzed for size-fractionated chlorophyll a ( $\mathrm{chl}$ a) to estimate food availability. This was determined in triplicate for each sample/sizeclass $(<180 \mu \mathrm{m}$ [total size fraction], 5 to $28 \mu \mathrm{m},<5 \mu \mathrm{m})$ and then analyzed spectrophotometrically following Parsons et al. (1984).

Growth. All live clams collected from the replicate boxes were pooled, transferred to the laboratory on ice, and immediately processed for condition index and for measuring the activity of the ETS. The SL of a random sample of 30 live clams from each strain was measured. These clams were then carefully shucked and the tissue was removed. The wet tissue weight and shell weight were determined separately. The tissue and shell samples were dried at $60^{\circ} \mathrm{C}$ for $>48 \mathrm{~h}$, then reweighed to obtain the DW. Instantaneous growth rate $(k)$ was calculated for SL and tissue DW for samples collected in May and June using the equation:

$$
k=\left(\ln x_{2}-\ln x_{1}\right) /\left(t_{2}-t_{1}\right)
$$

where $x_{2}$ and $x_{1}$ represent SL or tissue DW at times (d) $t_{2}$ and $t_{1}$ (Grizzle et al. 2001). The $k$ coefficient was then multiplied by 100 to express growth as $\% \mathrm{~d}^{-1}$. A condition index was calculated as a ratio of tissue DW to SL $\times 1000$ (Lucas \& Beninger 1985). The dried tissue sam- ples of each clam strain was pooled into 2 groups (selected and non-selected), placed in polypropylene vials, and stored at $-20^{\circ} \mathrm{C}$ for later determination of total protein, lipid, and carbohydrate content. Additionally, 6 to 9 live clams of each strain were measured and carefully shucked. The tissue was removed, weighed, and immediately used to measure ETS activity.

ETS activity. The ETS activity for each clam strain was determined using the method of Owens \& King (1975) as modified by Madon et al. (1998), where INTtetrazolium is reduced to INT-formazan when substituted for oxygen as the terminal electron acceptor. The modifications of Madon et al. (1998) included larger volumes of samples and reagents, increased concentration of $\mathrm{NADH}$, and eliminating NADPH as a substrate. All tissues and reagents were kept in an iced water bath $\left(0\right.$ to $\left.4^{\circ} \mathrm{C}\right)$ during the procedures. Tissue samples were placed in $3 \mathrm{ml}$ of ETS-B solution $(9.0 \mathrm{mg}$ $\mathrm{MgSO}_{4}, 1.5 \mathrm{~g}$ polyvinylpyrolidone [PVP], and $2.0 \mathrm{ml}$ of Triton X-100 in 0.1 M phosphate buffer, $\mathrm{pH}$ 8.5) and homogenized for three $20 \mathrm{~s}$ intervals. The homogenizer was rinsed with $1.0 \mathrm{ml}$ of ETS-B solution and the volume of the homogenate was recorded. From the homogenate, $2.0 \mathrm{ml}$ subsamples were removed and placed in centrifuge tubes. Samples were centrifuged at $4^{\circ} \mathrm{C}$ for $20 \mathrm{~min}$ at $10000 \times g$ and then $100 \mu \mathrm{l}$ of the supernatant was removed from the centrifuge tube and placed into a culture tube to which $2.25 \mathrm{ml}$ of substrate solution (10 mg NADH and $50 \mu \mathrm{l}$ of Triton X-100 in $0.1 \mathrm{M}$ phosphate buffer), $2.25 \mathrm{ml}$ of phosphate buffer, and $1.0 \mathrm{ml}$ of INT solution (100 mg INTtetrazolium chloride in double distilled water, $\mathrm{pH}$ 8.5) were added. These culture tubes were incubated for $20 \mathrm{~min}$ at the ambient temperature $\left( \pm 1^{\circ} \mathrm{C}\right)$ of Centerport Harbor on the sample date by placing them in a water bath or cold room. The reaction was stopped by adding $1.0 \mathrm{ml}$ of a quench solution (50\% formalin, $50 \%$ $1 \mathrm{M} \mathrm{H}_{3} \mathrm{PO}_{4}$ ). The absorbance of each sample was measured spectrophotometrically at $490 \mathrm{~nm}$. The absorbance value was corrected by a turbidity blank, which consisted of $4.0 \mathrm{ml}$ of ETS-B solution and $1.0 \mathrm{ml}$ of quench solution. ETS activity was calculated using the following equation (García-Esquivel et al. 2001):

$$
\begin{aligned}
\text { ETS } \mu \mathrm{mol} \mathrm{O} \mathrm{O}_{2} \mathrm{~h}^{-1} \mathrm{~g} \mathrm{DW}^{-1}= & {\left[\left(E_{\text {corr }} \times V_{\text {hom }} \times 60 / t \times 1 \times V_{\text {rxn }}\right)\right.} \\
& \left./\left(V_{\text {inc }} \times \mathrm{DW} \times 31.8\right)\right]
\end{aligned}
$$

where $E_{\text {corr }}$ is the corrected sample absorbance $\left(\mathrm{cm}^{-1}\right)$, $V_{\text {hom }}$ is the total homogenate volume (ml), $t$ is the incubation time (min), 60 is used to express the activity per hour, $V_{\text {rxn }}$ is the final reaction volume $(\mathrm{ml}), V_{\text {inc }}$ is the volume of homogenate used in the reaction assay $(\mathrm{ml})$, and DW is the DW of the tissue sample in the total homogenate $(g)$.

Biochemical analyses. Subsamples of the pooled dried tissue were used to determine the proximate biochemi- 
cal composition of the selected and non-selected clams. Total carbohydrate content was determined in triplicate using the phenol-sulfuric acid method of Dubois et al. (1956). A calibration curve was constructed using glucose as a standard. Proteins were quantified by organic nitrogen analysis with a CHN elemental analyzer using acetanilide as a standard, and a nitrogen-to-protein conversion factor of 5.8 (Gnaiger \& Bitterlich 1984). Total lipid content was estimated gravimetrically using the chloroform-methanol extraction of Folch et al. (1957). Results are expressed as biochemical content per unit DW and per individual clam. Since biochemical composition was determined from a pooled group of clams, the reported variance represents methodological variability, not variability among replicate boxes. Changes in carbohydrate composition were also described as changes in a carbohydrate budget $\left(\mathrm{CB}_{\mathrm{x} i}\right.$ Smolders et al. 2004) which was calculated as:

$\mathrm{CB}_{\mathrm{X}}=$

$\left[\left(T_{\mathrm{X}}-T_{\mathrm{X}-1}\right) \times\left(Y_{\mathrm{X}}-Y_{\mathrm{X}-1}\right) / 2\right]+\left(T_{\mathrm{X}}-T_{\mathrm{X}-1}\right) \times\left(Y_{\mathrm{X}-1}-Y_{0}\right)$

with $T_{X}$ being the number of days deployed in the boxes, $Y_{x}$ being the carbohydrate composition at time $x$, and $x-1$ being the composition at the previous measurement. Carbohydrate proximate composition was converted to its energy equivalent using an enthalpy of combustion of $17 \mathrm{~kJ} \mathrm{~g}^{-1}$ and results were expressed as $\mathrm{mJ}$ ind. ${ }^{-1}$.

Statistical analyses. A 2-way ANOVA was used to determine significant differences among sample dates and clam strains (selected and non-selected) for all measured variables. When a significant effect was found, a Tukey post hoc test was employed to deter- mine the differences between strains for each sample date. Student's $t$-tests were used to compare carbohydrate energy budgets between strains on each sample date. Adequate data transformations were performed where necessary; however, all data are presented as untransformed. Data are shown as the mean \pm SE. Statistical tests were conducted using SPSS version 15.

\section{RESULTS}

\section{Overwinter mortality}

Significant effects of sample date, strain type, and their interaction were observed for \%MO sample ${ }^{-1}$ (Fig. 1). Mortality increased from December through March for the selected clam strain and then did not change through April and May, and into June. In contrast, no significant differences were observed in non-selected clams through the sampling period. There were no significant differences in \%MO observed between clam strains from December through February; however, there were differences between strains in all measurements from March through June. During this period the average $\%$ MO sample ${ }^{-1}$ was approximately 47 and $25 \%$ for selected and non-selected clams, respectively.

\section{Environmental parameters}

In fall 2007, water temperature in Centerport Harbor decreased rapidly and remained $<5^{\circ} \mathrm{C}$ until the end of March. Temperature increased steadily through the

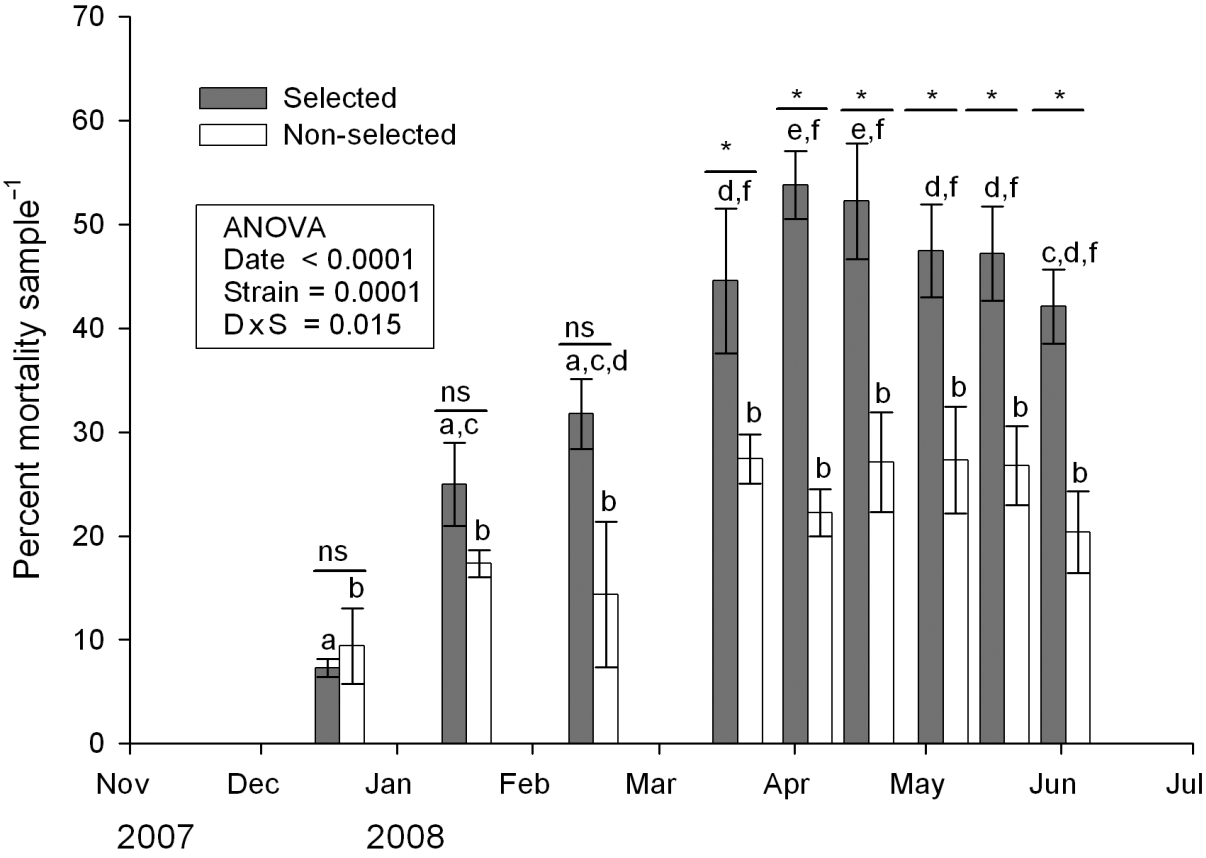

Fig. 1. Mercenaria mercenaria. Percent mortality sample ${ }^{-1}$ of selected and non-selected clams held in sediment-filled boxes and sampled monthly or biweekly between November 2007 and June 2008. Each value is the mean $\pm \mathrm{SE}$ of 5 boxes except in June when 10 boxes strain $^{-1}$ were sampled. Each box originally contained 30 clams. Results of 2-way ANOVA (sample date $\times$ strain, $\mathrm{D} \times \mathrm{S}$ ) are shown. Intra-strain means not sharing the same letters were significantly different between sampling dates as indicated by a Tukey post hoc test. The difference between the strains on each sampling date is marked as significant $\left({ }^{*}\right)$ or not significant (ns) 


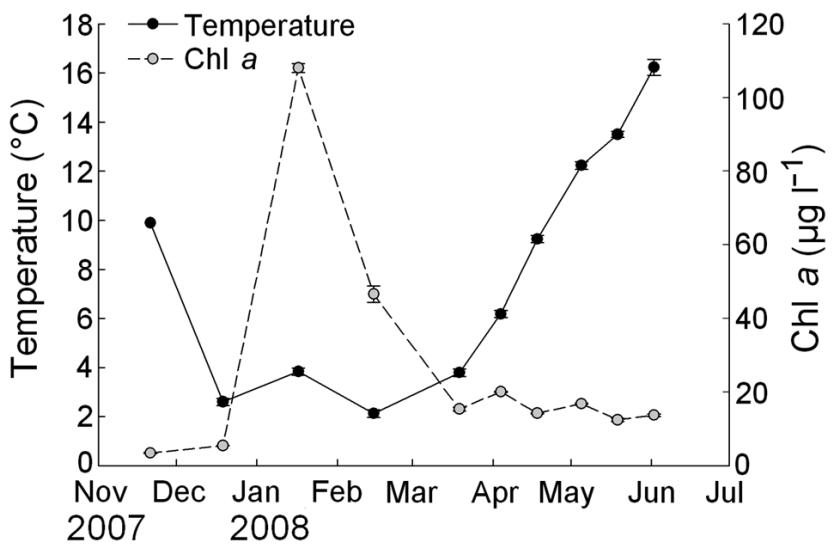

Fig. 2. Mean temperature $( \pm \mathrm{SE})$ for each sampling interval and total chl a concentration (mean $\pm \mathrm{SE}$ ) measured at the overwintering site in Centerport Harbor, NY

spring and was $16^{\circ} \mathrm{C}$ on the final sampling date (Fig. 2). Size-fractionated chl a showed negligible amounts of chl $a$ in the $<5 \mu \mathrm{m}$ fraction and no statistical differences (Student's $t$-test; $\mathrm{p}>0.05)$ between the total $(<180 \mu \mathrm{m})$ and 5-28 $\mu \mathrm{m}$ fraction. Therefore, only the data for total chl $a$ are presented (Fig. 2). Mean chl a was $4.5 \mu \mathrm{g} \mathrm{l^{-1 }}$ in November and December as the water temperature was falling. In January, the winter-spring bloom occurred and resulted in chl a levels $>100 \mu \mathrm{g} \mathrm{l}^{-1}$. The levels decreased through April and remained relatively stable through the remainder of the sampling period with a mean of $15.5 \mu \mathrm{g} \mathrm{l}^{-1}$.

\section{Proximate biochemical composition}

Protein, carbohydrate, and lipid concentrations ( $\mu \mathrm{g}$ mg $\mathrm{DW}^{-1}$ ) were significantly different among dates (ANOVA; $\mathrm{p}<0.001$ ) as were the interactions between date and strain (ANOVA; $\mathrm{p} \leq 0.024$ ). No significant effect of strain was found (ANOVA; $p$ > 0.05) (Figs. 3 to 5). Protein, carbohydrate, and lipid contents clam $^{-1}$ were significantly affected by date, strain, and the interaction of date and strain (Fig. A1 in Appendix 1). Protein concentration remained constant from November through April. In May and June, protein concentration decreased (Fig. 3) and increased when expressed as clam $^{-1}$ (Fig. A1a). There was clearly more protein clam $^{-1}$ in selected clams compared to non-selected clams (Fig. A1a). The carbohydrate concentrations were initially $143.08 \pm 8.29$ and $151.63 \pm 11.81 \mu \mathrm{g} \mathrm{mg}$ $\mathrm{DW}^{-1}$ for selected and non-selected clams, respectively. Carbohydrate concentrations decreased through April, reaching values as low as $104.71 \pm 13.14$ and $88.25 \pm 2.34 \mu \mathrm{g} \mathrm{mg} \mathrm{DW}{ }^{-1}$ for selected and non-selected clams, respectively (Fig. 4). Carbohydrates clam ${ }^{-1}$ remained constant in both clam strains through the win-

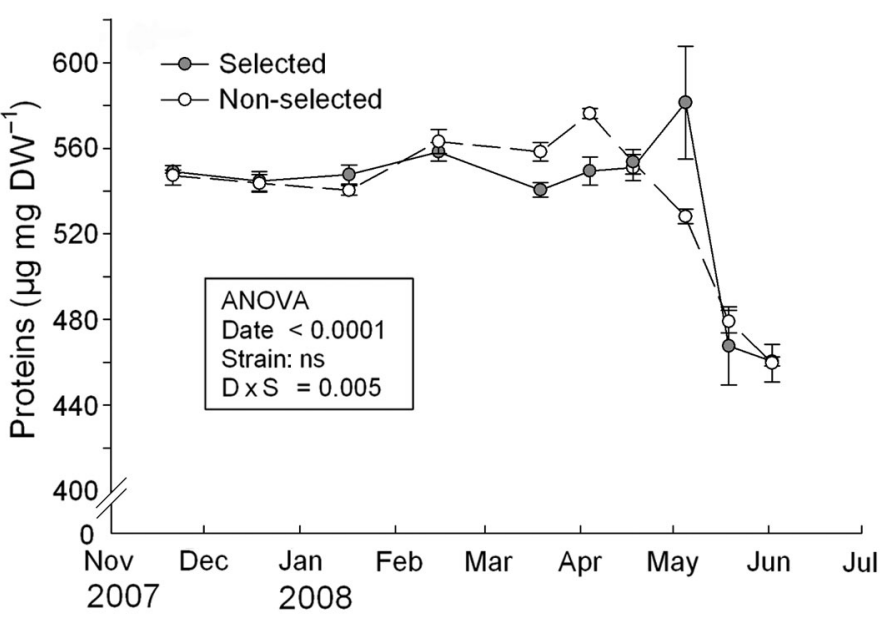

Fig. 3. Mercenaria mercenaria. Protein content (mean \pm SE) of selected and non-selected clams sampled monthly or biweekly between November 2007 and June 2008. Results of 2-way ANOVA (sample date $\times$ strain, $\mathrm{D} \times \mathrm{S}$ ) are shown. ns: not significant

ter months. In May and June, both carbohydrate concentration and carbohydrate clam $^{-1}$ increased significantly in both strains, although greater values were observed in selected clams (Fig. 4, Fig. A1b). Lipid concentration varied between 61 and $86 \mu \mathrm{g} \mathrm{mg} \mathrm{DW}{ }^{-1}$ for both strains throughout the study (Fig. 5). Lipid content clam $^{-1}$ was higher in the selected clams throughout the study and increased significantly in both strains in May and June (Fig. A1c).

The carbohydrate energy budget (Fig. 6) decreased for all samples collected from December through

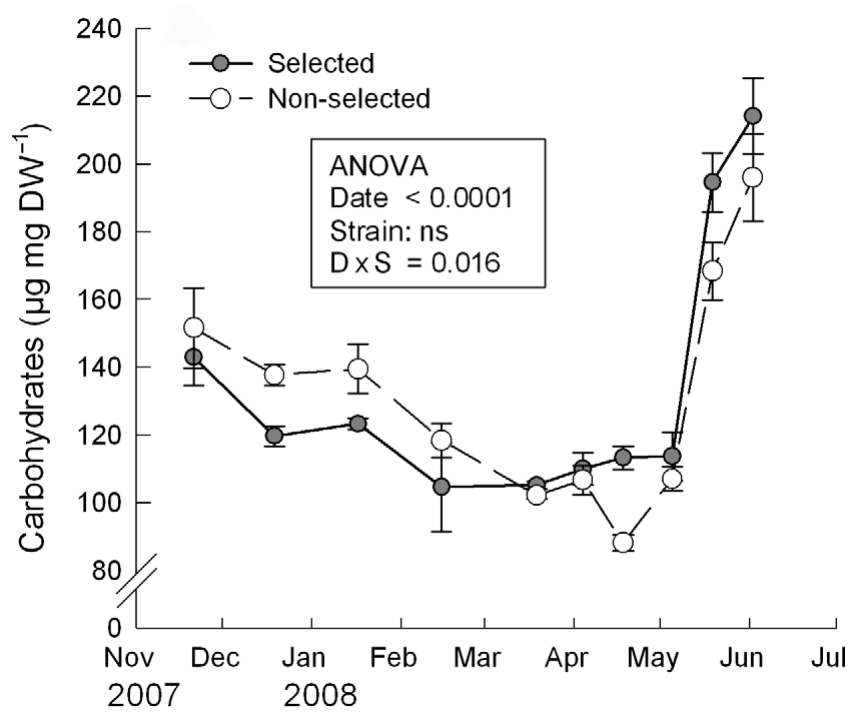

Fig. 4. Mercenaria mercenaria. Carbohydrate content (mean $\pm \mathrm{SE}$ ) of selected and non-selected clams sampled monthly or biweekly between November 2007 and June 2008. Results of 2 -way ANOVA (sample date $\times$ strain, $\mathrm{D} \times \mathrm{S}$ ) are shown. ns: not significant 


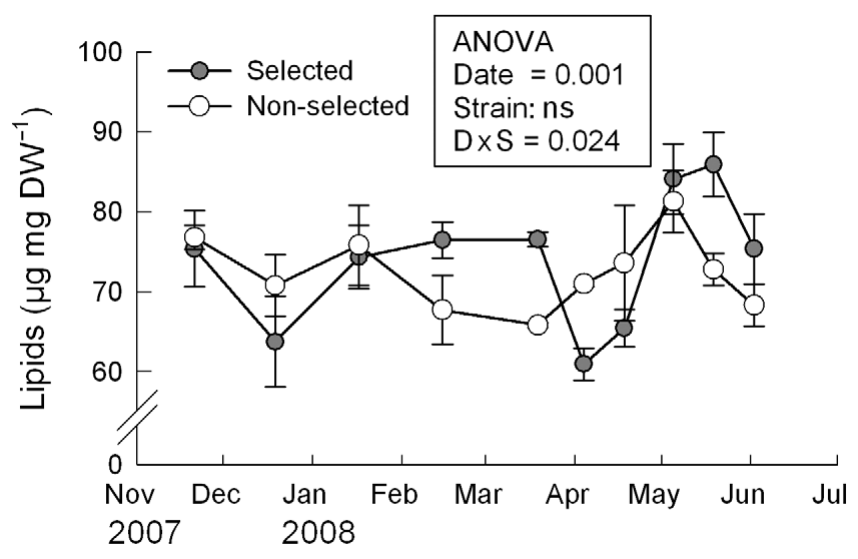

Fig. 5. Mercenaria mercenaria. Lipid content (mean $\pm \mathrm{SE}$ ) of selected and non-selected clams sampled monthly or biweekly between November 2007 and June 2008. Results of 2-way ANOVA (sample date $\times$ strain, $\mathrm{D} \times \mathrm{S}$ ) are shown. ns: not significant

the beginning of May. A significantly (Student's $t$-test; $\mathrm{p}<0.05$ ) greater loss in the carbohydrate energy budget was observed in the selected clams from January through early April. At the end of May and into June, the carbohydrate energy budget increased for both strains, but the increase was greater in selected clams (Fig. 6).

\section{ETS activity}

A significant effect of date $\left(\right.$ ANOVA $\left._{i} \mathrm{p}<0.0001\right)$ was observed on the ETS activity of the selected and nonselected clams over the study period, which is expected since the assays were conducted at ambient temperatures measured in the field. There was no observed effect of strain and the interaction of date and strain (Fig. 7). ETS activity was approximately $102 \mu \mathrm{mol} \mathrm{O}_{2}$ $\mathrm{h}^{-1} \mathrm{~g} \mathrm{DW}^{-1}$ in both strains in November 2007 and then decreased significantly in December as water temperature decreased (Fig. 1). ETS activity remained very low through the winter months when water temperature was $<5^{\circ} \mathrm{C}$ and then increased in April as the water temperature began to rise. ETS activity reached the highest observed values of $127.27 \mu \mathrm{mol} \mathrm{O} \mathrm{h}^{-1} \mathrm{~g} \mathrm{DW}^{-1}$ for selected and $151.53 \mu \mathrm{mol} \mathrm{O}_{2} \mathrm{~h}^{-1} \mathrm{~g} \mathrm{DW}^{-1}$ for non-selected clams in early May. Following this peak, ETS activity decreased in late May and June to a mean value of $68.35 \mu \mathrm{mol} \mathrm{O} \mathrm{h}^{-1} \mathrm{~g} \mathrm{DW}^{-1}$ for both strains.

\section{Growth and condition index}

Analysis of measurements of SL, tissue DW, and condition index indicated a significant effect (ANOVA; $\mathrm{p}<$ 0.0001 ) of date, strain, and the interaction of date and

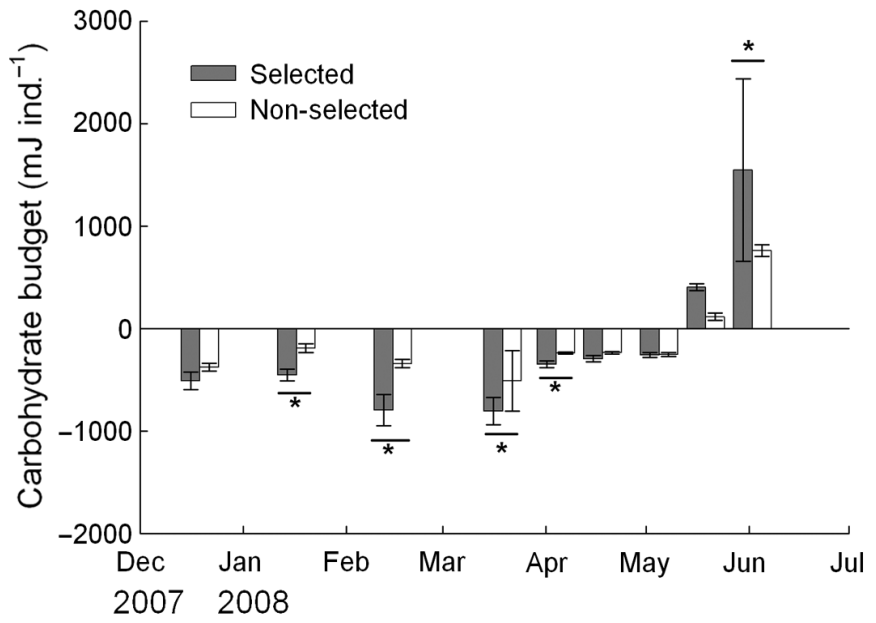

Fig. 6. Mercenaria mercenaria. Carbohydrate energy budget (mean $\pm \mathrm{SE}$ ) of selected and non-selected clams sampled monthly or biweekly between November 2007 and June 2008. ${ }^{*}$ Significant difference (Student's $t$-test; $\mathrm{p}<0.05$ ) between strain types

strain (Fig. 8). In general, selected clams had higher observed mean tissue DW and condition index than non-selected clams. Mean SL was also higher in selected clams; however, there was greater variability in SL in non-selected clams as indicated by the large error bars (Fig. 8a). No significant decreases in tissue DW or condition index were observed during the winter months despite the decreases in carbohydrates (Figs. 4 \& 6). SL, tissue DW, and condition index did increase significantly for both strains in late May and June along with ETS activity. Selected clams had a greater increase in condition index during May and June and also had greater SL and tissue DW growth

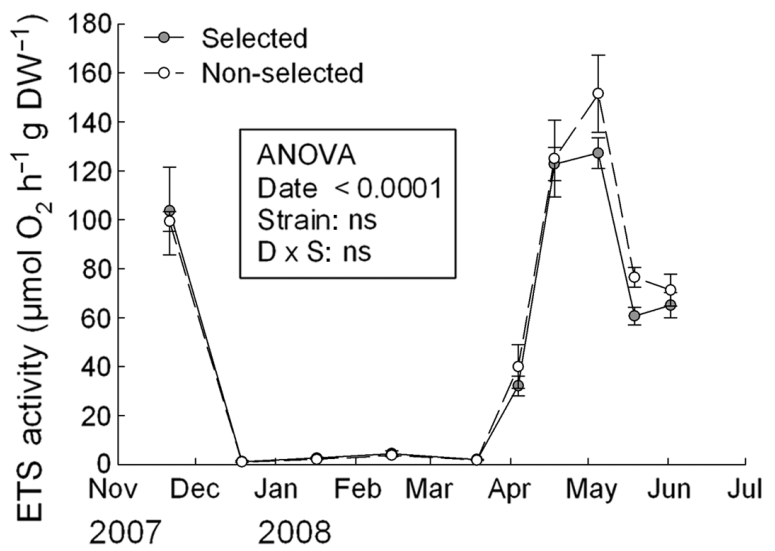

Fig. 7. Mercenaria mercenaria. Electron transport system (ETS) activity (mean \pm SE) of selected and non-selected clams sampled monthly or biweekly between November 2007 and June 2008. Results of 2-way ANOVA (sample date $\times$ strain, $\mathrm{D} \times \mathrm{S}$ ) are shown. ns: not significant 

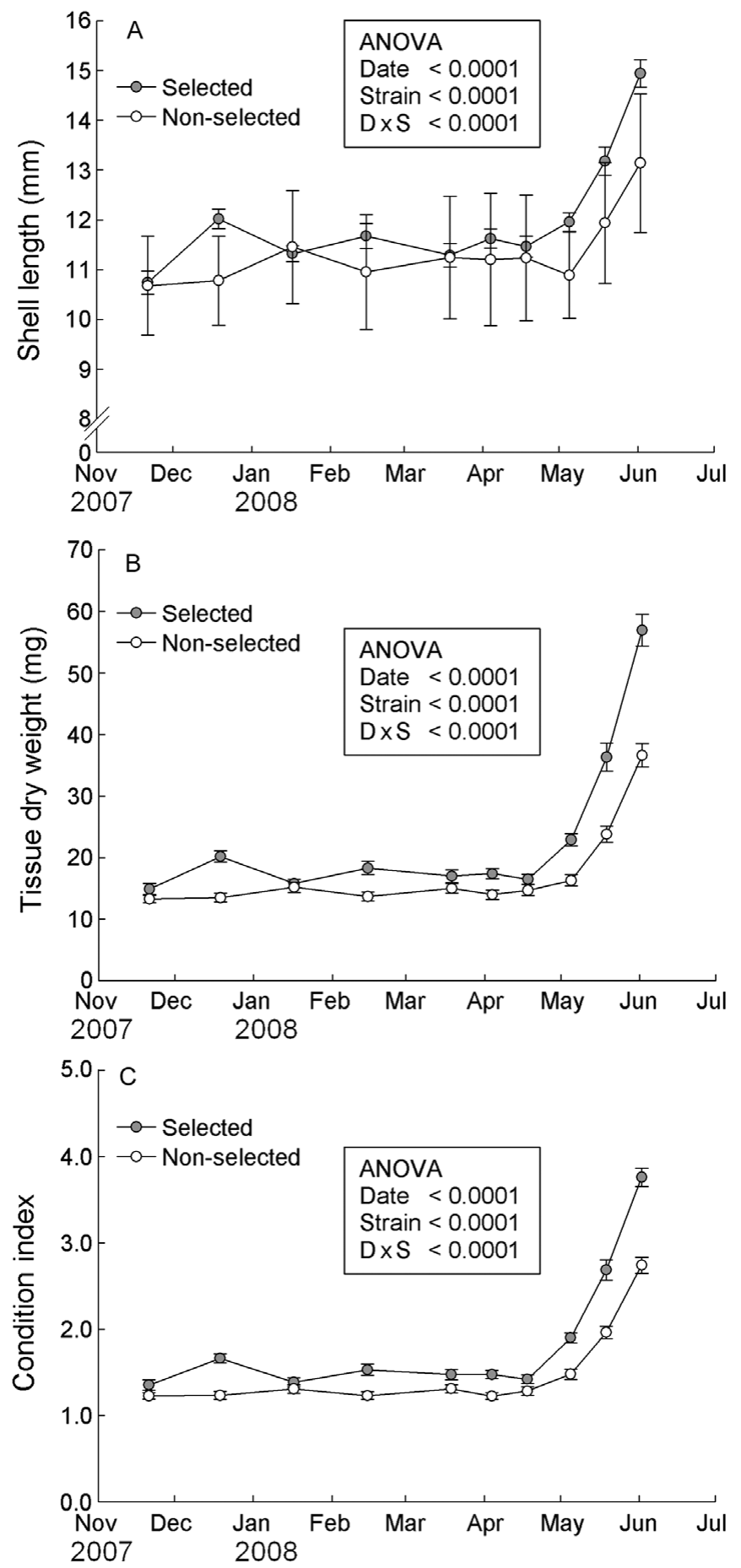

Fig. 8. Mercenaria mercenaria. (a) Shell length, (b) tissue dry weight, and (c) condition index of selected and non-selected clams sampled monthly or biweekly between November 2007 and June 2008. Results of 2-way ANOVA (sample date $\times$ strain, $\mathrm{D} \times \mathrm{S}$ ) are shown

rates. Calculated instantaneous growth rates were 0.79 and $0.68 \% \mathrm{~d}^{-1}$ on the basis of SL, and 3.25 and $2.89 \%$ $\mathrm{d}^{-1}$ on the basis of tissue DW, for selected and nonselected clams, respectively.

\section{DISCUSSION}

The present field study demonstrated a significant genetic component in overwinter mortality in juvenile hard clams. During the overwintering period of 20072008, hard clams selected for fast growth experienced mortality of approximately $47 \%$ and non-selected clams had mortality of $25 \%$. There was no significant difference in \%MO among the sample dates in nonselected clams. In contrast, a significant increase in \%MO was observed in selected clams between February and late March. This higher mortality coincided with an increase in water temperature. Zarnoch \& Schreibman (2008) described a winter-spring mortality (up to $0.99 \% \mathrm{~d}^{-1}$ ) of juvenile hard clams (SL $10 \mathrm{~mm}$ ) when water temperature increased above $5^{\circ} \mathrm{C}$ and food levels, as measured by chl a concentration, were low. In the present study, mortality was observed through the winter in both strains, but mortality increased significantly in the selected clams from February to March. Water temperature reached $4^{\circ} \mathrm{C}$ during the first week of March and then fluctuated between 4 and $6^{\circ} \mathrm{C}$ through March and early April. Hard clams are inactive when water temperatures are $<5^{\circ} \mathrm{C}$ (Loosanoff 1939, Ansell 1964). It is likely that the small changes in temperature during March moved the juvenile hard clams from an inactive to active physiological state resulting in physiological stress and thus additional mortality. Our results are consistent with other similar studies (Bricelj et al. 2007, Gionet et al. 2009). Gionet et al. (2009) found an increase in mortality (up to $47.2 \%$ ) in selected clams (SL $\sim 9 \mathrm{~mm}$ ) during May when water temperature increased above $5^{\circ} \mathrm{C}$ in a field trial conducted in Atlantic Canada; nonselected clams (SL $\sim 6 \mathrm{~mm}$ ) had mortality up to $10.8 \%$, with most of it also occurring in May. Gionet et al. (2009) and Zarnoch \& Schreibman (2008) found negligible mortality occurring during the winter months and significant mortality occurring as water temperatures were increasing in spring. Gionet et al. (2009) did not report food availability at their field site so it is unclear if this had any influence on clam mortality.

The greatest mortality in the present study was not related to food availability as chl a concentration was $>12.5 \mathrm{\mu g} \mathrm{l}^{-1}$ from February through June. In addition the winter-spring phytoplankton bloom peaked in February when water temperatures were $<5^{\circ} \mathrm{C}$, clams were inactive, and significant mortality was observed. Between December and February, mean percent mortality was 21.3 and $13.7 \%$ for the selected and nonselected clams, respectively. Bricelj et al. (2007) conducted several laboratory trials aimed at understanding the causes of overwinter mortality in general and to specifically inform aquaculture efforts in Atlantic Canada. These authors held selected and non-selected 
Clams (SL $\sim 6$ to $8 \mathrm{~mm}$ ) at 1,7 , and $12{ }^{\circ} \mathrm{C}$ for periods up to $150 \mathrm{~d}$. The greatest mortality (>70\% cumulative mortality) occurred in the $1^{\circ} \mathrm{C}$ treatment with selected clams. Therefore, the work of Bricelj et al. (2007) also demonstrates that mortality occurred during the winter period $\left(1^{\circ} \mathrm{C}\right)$ and that it had a distinct genetic component.

The observed mortality during early winter in the present study as well as the mortality observed by Bricelj et al. (2007) cannot be correlated with an increase in temperature (as in Gionet et al. 2009) or lack of food (as in Zarnoch \& Schreibman 2008). There was, however, a relationship between mortality and loss of carbohydrates. In the present study, a decline in carbohydrate concentration occurred through the winter period and into early spring in both clam strains. Similarly, Bricelj et al. (2007) found a significant decrease in carbohydrate concentration in selected clams when comparing the initial measurement to the final (no carbohydrate data were given for the non-selected clams). The calculated carbohydrate energy budget in the present study provides a useful perspective on the greater mortality in the selected clams. The carbohydrate energy budget better reflects physiological changes between sampling periods than the absolute value of carbohydrate reserves (Smolders et al. 2004). Decreases in the carbohydrate energy budget were observed from December through early May in both clam strains, suggesting the clams were being challenged physiologically going into the winter period. Significantly greater decreases in the carbohydrate energy budget were observed in the selected clams compared to the non-selected clams from January through early April. These decreases coincided with the significant increase in mortality observed between February and March in the selected clams. Measurements of ETS activity during this period were near zero, thus the hard clams were likely using anaerobic pathways for catabolism of the carbohydrate stores. Anaerobic metabolism has not been well studied in hard clams and a breakdown of total metabolism into aerobic and anaerobic components, which has been done in other bivalves, is lacking for Mercenaria mercenaria (Grizzle et al. 2001). The present study and the data presented by Bricelj et al. (2007) suggest the need for future work on anaerobic metabolism in juvenile hard clams over the winter.

The effect of genetic selection was clearly evident during spring growth in juvenile hard clams as indicated by the energetic differences between the 2 clam strains. The carbohydrate energy budget increased in both clam strains during the last 2 sampling dates in late May and June, suggesting an improvement in physiological condition. Selected clams seemed to recover more rapidly from the overwinter stress as indicated by significantly greater increases in the carbohydrate energy budget. The last 2 sample dates were also when growth was observed. Again, selected clams showed greater increases in tissue DW, SL, and thus condition index. The greater growth in selected clams was obviously due to previous selection for rapid growth, but it is also interesting that selection apparently also resulted in a more uniform SL distribution among the cohort. The error bars were much larger for the SL of non-selected clams compared to selected clams. In addition, it was also clear that variability in the tissue DW of non-selected clams was lower even though the units were different.

Another interesting observation regarding spring growth was that none was observed until May even though food availability and water temperature were sufficient to support growth before then. Chl a levels were $>12.5 \mathrm{\mu g} \mathrm{l}^{-1}$ from February through June, which is sufficient to support growth. Zarnoch \& Schreibman (2008) suggested that chl a values $>3 \mu g \mathrm{l}^{-1}$ can support growth during spring warming while lesser values may be insufficient. Growth occurs in hard clams at temperatures $>7^{\circ} \mathrm{C}$ (Ansell 1968), while temperatures between 15 and $25^{\circ} \mathrm{C}$ have been shown to be optimal (Grizzle et al. 2001). Water temperature reached $7^{\circ} \mathrm{C}$ on 1 April and the maximum temperature recorded was $18^{\circ} \mathrm{C}$ in June. Therefore, the question remains, why did growth not occur in April despite appropriate food and water temperature? One possible explanation is the poor nutritional quality of the phytoplankton community. As previous work has shown, hard-clam growth and reproduction can be limited by phytoplankton communities dominated by microalgae of $<5 \mu$ m diameter (Weiss et al. 2007, Newell et al. 2009). However, this is unlikely to be the explanation in the present study since size-fractionated chl $a$ analyses did not reveal any microalgae in the $<5 \mu \mathrm{m}$ size class. The answer may be related to metabolic acclimation as indicated by the ETS activity data.

It was hypothesized that selected clams would have higher levels of ETS activity during spring warming, which would make them more susceptible to winterspring mortality. As expected, ETS activity closely followed changes in ambient water temperature through the winter and early spring. However, there were no significant differences between the clam strains throughout the study, suggesting that the higher overwinter mortality in the selected clam strain was not associated with higher aerobic metabolic rates as estimated by ETS activity. ETS activity was also quite low while water temperatures were $<5^{\circ} \mathrm{C}$, which was the period when losses of carbohydrates were observed. Thus the juvenile hard clams were likely using anaerobic pathways for maintenance. Future work comparing anaerobic metabolism of selected and non-selected juvenile clams during the overwinter period may explain the greater losses of carbohydrates in the selected clams. 
Zarnoch \& Schreibman (2008) suggested that winterspring mortality occurs when metabolic activity is enhanced as clams become active during spring warming $\left(>5^{\circ} \mathrm{C}\right.$ ) and food levels are low (chl $\left.a<3 \mu \mathrm{g} \mathrm{l}^{-1}\right)$. However, these authors did not measure metabolic activity. One aim in the present study was to test this hypothesis in the field. Measured ETS activity increased as water temperature increased from April through early May. It then decreased significantly in late May and remained at this level in June (Fig. 7). This decrease in ETS activity was interesting since water temperature was still increasing in early June and oxygen utilization would be expected to increase with temperature at least up to the maximum threshold where metabolic activity becomes curtailed $\left(27^{\circ} \mathrm{C}\right.$; Hamwi 1969). These last 2 samples also coincided with the period of significant spring growth. Therefore, we speculate that metabolic activity was exaggerated during the spring warming period (5 to $12^{\circ} \mathrm{C}$ ) and then as acclimation occurred, metabolic activity may have been reduced. When metabolic activity is reduced, the balance of energetic demand then favors growth. This hypothesis corroborates and further elucidates the model of Zarnoch \& Schreibman (2008) to explain winter-spring mortality. In the present study, the high food availability during spring warming, indicated by chl a levels $>12.5 \mu \mathrm{g} \mathrm{l}^{-1}$, was sufficient to support the exaggerated metabolic demands of the hard clams and thus not cause additional mortality. Accordingly, if food levels had been low ( $\mathrm{chl} a<3 \mu \mathrm{g} \mathrm{l}^{-1}$ ), greater mortality would have been expected.

Another intriguing facet to the ETS activity data is the similarity between the measurements made during spring warming and the initial measurement made in November. Again, it is suspected that during spring warming, metabolic activity was exaggerated due to the changing temperature. ETS activity measurements in the fall and early spring were $>100 \mu \mathrm{mol} \mathrm{O}_{2} \mathrm{~h}^{-1} \mathrm{~g}$ $\mathrm{DW}^{-1}$ and conversely the measurements made where suspected acclimation occurred were much lower $\left(68 \mu \mathrm{mol} \mathrm{O} \mathrm{O}_{2} \mathrm{~h}^{-1} \mathrm{~g} \mathrm{DW}^{-1}\right.$ ). Therefore in the fall when water temperatures are decreasing, hard clams may be subject to exaggerated metabolic demands similar to what they experience during spring warming. This would then place higher energy demands on the clams, which would have to be met by ambient food supply. At the time the clams were deployed in November 2007, chl a concentration was approximately $3.5 \mu \mathrm{g} \mathrm{l}^{-1}$, which is similar to the low food levels $\left(<3 \mu \mathrm{g} \mathrm{l}^{-1}\right)$ described as insufficient to support metabolic demand by Zarnoch \& Schreibman (2008). Therefore, the fall-to-winter transition may also be physiologically stressful and leave hard clams challenged as they enter the winter. This may explain why hard clams were reducing their carbohydrate stores as early as December. Ideally, future studies could take measurements of ETS activity in late summer or early fall to identify a change in ETS activity as temperatures decrease, which would suggest a lack of acclimation. These periods of temperature transition appear to be critical to understanding the physiological mechanisms associated with overwinter mortality of juvenile hard clams.

The present study provides further evidence for a genetic component to the overwinter mortality of juvenile hard clams. Mortality in selected clams was nearly twice that of non-selected clams. Interestingly, juvenile hard clams produced from an unselected Maine broodstock had $>99 \%$ overwinter survival (Beal et al. 2009). It is unclear whether this high survival was due to the Maine clams being genetically adapted to survive overwinter conditions or if the culture methodology (Beal et al. 1995, 2009) used contributed to the high survival. Comparative studies of the performance of different hard clam stocks (e.g. geographic, selected, non-selected, etc.) would be useful.

Mortality in the present study was associated with a decrease in carbohydrate reserves as also observed by Zarnoch \& Schreibman (2008) and Bricelj et al. (2007). In addition, the loss of reserves was greater in selected clams. Following the definition of physiological tradeoffs by Angilletta et al. (2003), the present study may suggest a link between increased growth (via selection) and overwinter survival, which affects the fitness of genotypes and prevents these traits from evolving independently. We speculate that the greater loss of carbohydrate reserves in the selected clams during the overwinter period may be a physiological trade-off for increased growth rate. In order to fully explore this hypothesis, future work might examine the physiological processes responsible for differences in growth rate and couple it with an understanding of the genetic component of growth.

Acknowledgements. This work was partially funded by a Sounds Conservancy Grant (\#259) from the Quebec-Labrador Foundation to C.B.Z. We thank Dr. M. P. Schreibman and the Biology Department at Brooklyn College (CUNY) for use of laboratory facilities. In addition, we acknowledge the field and laboratory assistance provided by Y. Abdelhadi, S. O'Donnell, C. Humphrey, J. Eddings, and L. Brousseau. G. Hulse and H. Acker of the Town of Huntington's Department of Maritime Services provided the clams for this study. This manuscript was significantly improved by the thoughtful comments and suggestions of 3 reviewers.

\section{LITERATURE CITED}

Angilletta MJ Jr, Wilson RS, Navas CA, James RS (2003) Tradeoffs and the evolution of thermal reaction norms. Trends Ecol Evol 18:234-240

Ansell AD (1964) Some parameters of growth of mature 
Venus mercenaria (L.). J Cons Int Explor Mer 29:214-220

Ansell AD (1968) The rate of growth of the hard clam Mercenaria mercenaria (L.) throughout the geographical range. J Cons Int Explor Mer 31:364-409

Bayne BL (2004) Phenotypic flexibility and physiological tradeoffs in the feeding and growth of marine bivalve mollusks. Integr Comp Biol 44:425-432

Beal BF, Lithgow C, Shaw D, Renshaw S, Ouellette D (1995) Overwintering hatchery-reared individuals of the softshell clam, Mya arenaria L.: a field test of site, clam size, and intraspecific density. Aquaculture 130:145-158

Beal BF, Protopopescu G, Yeatts K, Porada JL (2009) Experimental trials on the nursery, overwintering, and field grow-out of hatchery-reared northern quahogs (hard clams, Mercenaria mercenaria (L.)), in eastern Maine. J Shellfish Res 28:763-776

Belding DL (1912) A report upon the quahog and oyster fisheries of Massachusetts. Wright \& Potter Printing, Boston, MA

Bricelj VM, Ouellette C, Anderson M, Brun N, Pernet F, Ross N, Landry $T$ (2007) Physiological and biochemical responses of juvenile quahogs, Mercenaria mercenaria, to low temperatures: potential for mitigation of overwintering mortalities. Can Tech Rep Fish Aquat Sci 2739

$>$ Cammen LM, Corwin S, Christensen JP (1990) Electron transport system (ETS) activity as a measure of benthic macrofaunal metabolism. Mar Ecol Prog Ser 65:171-182

Castagna M (2001) Aquaculture of the hard clam, Mercenaria mercenaria. In: Kraeuter JN, Castagna M (eds) Biology of the hard clam. Elsevier, Amsterdam, p 675-693

Chanley PE (1961) Inheritance of shell markings and growth in the hard clam, Venus mercenaria. Proc Natl Shellfish Assoc 50:163-169

Dubois M, Gilles KA, Hamilton JK, Rebers PA, Smith F (1956) Colorimetric method for determination of sugars and related substances. Anal Chem 28:350-356

Fanslow DL, Nalepa TF, Johengen TH (2001) Seasonal changes in the respiratory electron transport system (ETS) and respiration of the zebra mussel, Dreissena polymorpha, in Saginaw Bay, Lake Huron. Hydrobiologia 448:61-70

Folch J, Lees M, Sloane Stanley GH (1957) A simple method for the isolation and purification of total lipides from animal tissues. J Biol Chem 226:497-507

Ford SE (2001) Pests, parasites, diseases and defense mechanisms of the hard clam, Mercenaria mercenaria. In: Kraeuter JN, Castagna M (eds) Biology of the hard clam. Elsevier, Amsterdam, p 591-628

> García-Esquivel Z, Bricelj VM, Gonzalez-Gomez MA (2001) Physiological basis for energy demands and early postlarval mortality in the Pacific oyster, Crassostrea gigas. J Exp Mar Biol Ecol 263:77-103

Gionet CE, Mayrand E, Landry T (2009) The effects of energy reserves and cryoprotectants on overwintering mortality in Mercenaria mercenaria notata (Say 1822) at two tidal levels. Aquacult Int 17:589-605

Gnaiger E, Bitterlich G (1984) Proximate biochemical composition and caloric content calculated from elemental CHN analysis: a stoichiometric concept. Oecologia 62:289-298

Grizzle RE, Bricelj VM, Shumway SE (2001) Physiological ecology of Mercenaria mercenaria. In: Kraeuter JN, Castagna M (eds) Biology of the hard clam. Elsevier, Amsterdam, p 305-382

Hamwi A (1969) Oxygen consumption and pumping rate of the hard clam Mercenaria mercenaria L. PhD dissertation, Rutgers University, New Brunswick, NJ

Humphrey CM, Walker RL (1982) The occurrence of Mercenaria mercenaria form notata in Georgia and South Carolina: calculations of phenotypic and genotypic frequencies. Malacologia 23:75-79

Kraeuter JN (2001) Predators and predation. In: Kraeuter JN, Castagna M (eds) Biology of the hard clam. Elsevier, Amsterdam, p 441-589

Loosanoff VL (1939) Effect of temperature upon shell movements of clams, Venus mercenaria (L.). Biol Bull 76: $171-182$

Lucas A, Beninger PG (1985) The use of physiological condition indices in marine bivalve aquaculture. Aquaculture 44:187-200

Madon SP, Schneider DW, Stoeckel JA (1998) In situ estimation of zebra mussel metabolic rates using the electron transport system (ETS) assay. J Shellfish Res 17:195-203

Newell RIE, Tettelbach ST, Gobler CJ, Kimmel DG (2009) Relationships between suspension-feeding hard clams Mercenaria mercenaria and phytoplankton community structure. Mar Ecol Prog Ser 387:179-196

$>$ Owens TG, King FD (1975) The measurement of respiratory electron-transport system activity in marine zooplankton. Mar Biol 30:27-36

Parsons TR, Maita Y, Lalli CM (1984) A manual of chemical and biological methods for seawater analysis. Pergamon Press, New York, NY

Pernet F, Tremblay R, Gionet C, Landry T (2006) Lipid remodeling in wild and selectively bred hard clams at low temperatures in relation to genetic and physiological parameters. J Exp Biol 209:4663-4675

Smolders R, Bervoets L, De Coen W, Blust R (2004) Cellular energy allocation in zebra mussels exposed along a pollution gradient: linking cellular effects to higher levels of biological organization. Environ Pollut 129:99-112

Weiss MB, Curran PB, Peterson BJ, Gobler CJ (2007) The influence of plankton composition and water quality on hard clam (Mercenaria mercenaria L.) populations across Long Island's south shore lagoon estuaries (New York, USA). J Exp Mar Biol Ecol 345:12-25

Zarnoch CB, Schreibman MP (2008) Influence of temperature and food availability on the biochemical composition and mortality of juvenile Mercenaria mercenaria (L.) during the over-winter period. Aquaculture 274:281-291 


\section{Appendix 1}
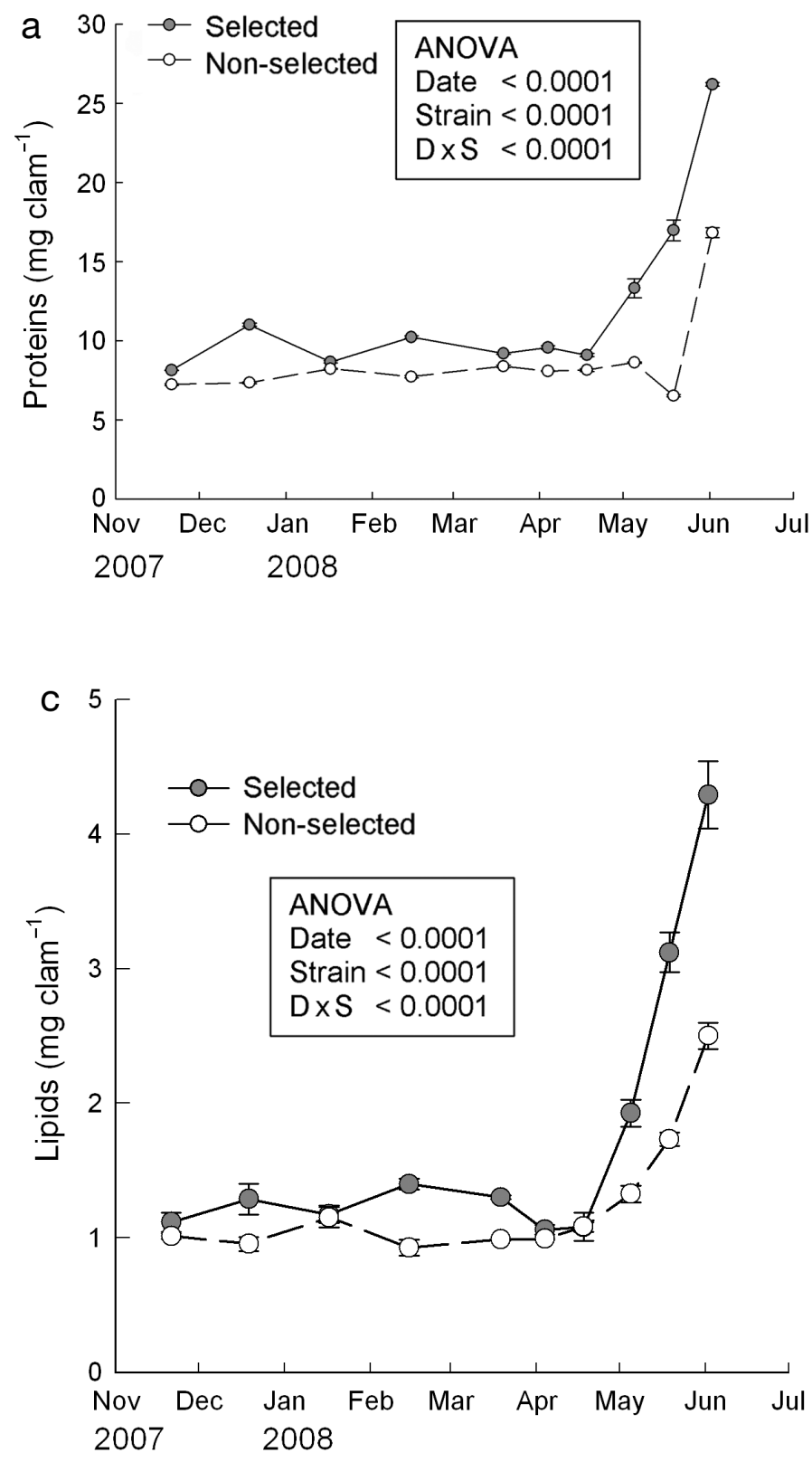

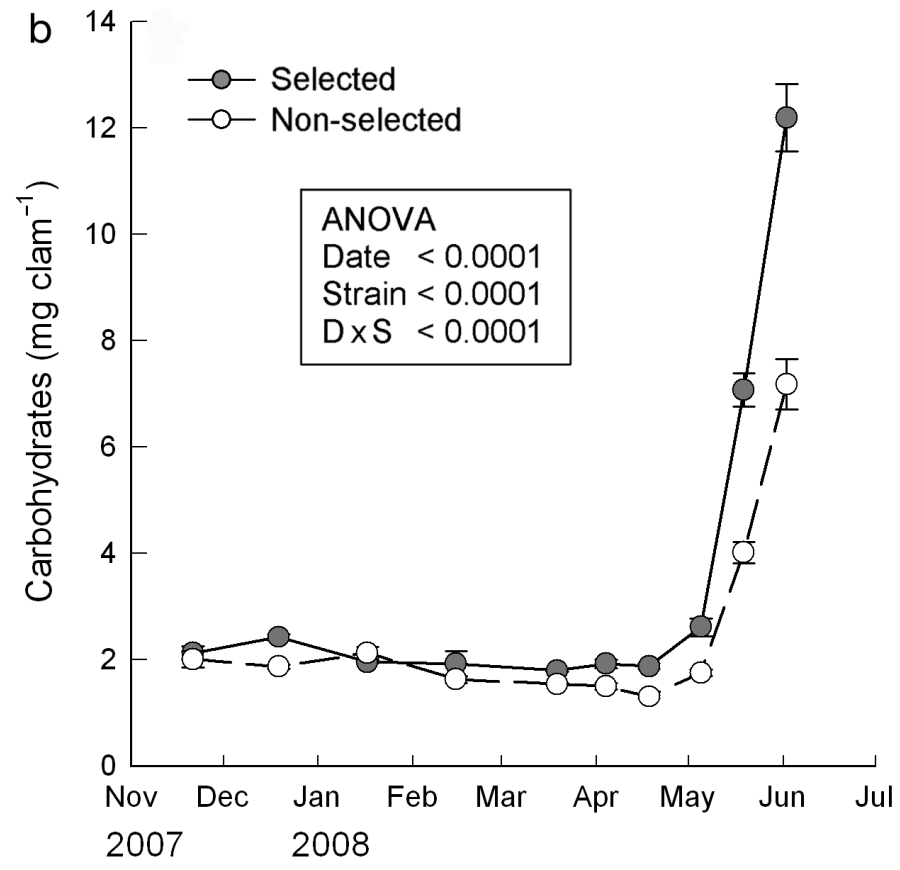

Fig. A1. Mercenaria mercenaria. (a) Protein, (b) carbohydrate, and (c) lipid content (mean $\pm \mathrm{SE}$ ) shown as $\mathrm{mg} \mathrm{clam}^{-1}$ of selected and non-selected clams sampled monthly or biweekly between November 2007 and June 2008. Results of

2 -way ANOVA (sample date $\times$ strain, $\mathrm{D} \times \mathrm{S}$ ) are shown 